\title{
The Newest Digital Technologies in Education and The Prospects of Their Implementation in Ukraine
}

\section{Las nuevas tecnologías digitales en educación y las perspectivas de su implementación en Ucrania}

\author{
Anatolii Kulish* \\ Sumy State University, Sumy, Ukraine \\ ORCID: https://orcid.org/0000-0003-0226-8660 \\ Valerii Radul \\ Volodymyr Vynnychenko Central Ukrainian State Pedagogical University, Kropyvnytskyi, \\ Ukraine \\ ORCID: https://orcid.org/0000-0002-1538-0638 \\ Yaroslav Haleta \\ Volodymyr Vynnychenko Central Ukrainian State Pedagogical University, Kropyvnytskyi, \\ Ukraine \\ ORCID: https://orcid.org/0000-0002-1159-7186

\section{Oksana Filonenko} \\ Volodymyr Vynnychenko Central Ukrainian State Pedagogical University, Kropyvnytskyi, \\ Ukraine \\ ORCID: https://orcid.org/0000-0003-1211-6492

\section{Ihor Karikh} \\ Sumy State University, Sumy, Ukraine \\ ORCID: https://orcid.org/0000-0002-7637-0687
}

Received 02-12-20 Revised 03-13-20 Accepted 07-13-20 On line 08-29-20

*Correspondence

Email: kulish-an@tanu.pro
Cite as:

Kulish, A., Radul, V., Haleta, Y., Filonenko, O., Karikh, I. (2020). The Newest Digital Technologies in Education and The Prospects of Their Implementation in Ukraine. Propósitos y Representaciones, 8 (SPE2), e684. Doi: http://dx.doi.org/10.20511/pyr2020.v8nSPE2.684 


\section{Summary}

The relevance of this article is due to the constitutional obligation of the state to provide the population with a high level of education. The purpose of the article is to carry out scientific research on the issue of educational digitization in developed countries of the world and to develop a program of educational digitization in Ukraine. The leading research methods are general scientific and specific research methods, including methods of logic, analysis, comparison and more. The results of this study are to outline the real need of modern society in the digitization of education, to determine the legal and organizational basis of such processes in the country, to develop an effective, step-by-step program for the digitization of education in Ukraine. The significance of the obtained results is reflected in the fact that this study can serve as a basis for outlining future changes to the current legislation of Ukraine on the issues of the digitization of education and reformatting the work of the relevant state bodies in the educational sphere.

Keywords: Digitalization of Education; Models of Digitalization; Innovative Technologies, Technical Progress; Educational Services Client.

\section{Resumen}

La relevancia de este artículo se debe a la obligación constitucional del estado de proporcionar a la población un alto nivel de educación. El objetivo del artículo es llevar a cabo una investigación científica sobre el tema de la digitalización educativa en los países desarrollados del mundo y desarrollar un programa de digitalización educativa en Ucrania. Los principales métodos de investigación son métodos generales de investigación científica y específica, que incluyen métodos de lógica, análisis, comparación y más. Los resultados de este estudio son para delinear la necesidad real de la sociedad moderna en la digitalización de la educación, para determinar la base legal y organizativa de tales procesos en el país, para desarrollar un programa eficaz y paso a paso para la digitalización de la educación. en Ucrania. La importancia de los resultados obtenidos se refleja en el hecho de que este estudio puede servir como base para delinear cambios futuros a la legislación actual de Ucrania sobre los temas de la digitalización de la educación y reformatear el trabajo de los organismos estatales relevantes en la esfera educativa.

Palabras clave: Digitalización de la educación; Modelos de digitalización; Tecnologías innovadoras; Progreso técnico; Servicios educativos al cliente.

\section{Introduction}

Scientific and technological progress in the XXI century is developing at a breakneck pace. The most recent technologies that were considered ordinary fiction ten years ago are already working in various areas of our lives. These technological processes have become a regular feature of the historical development of mankind at this stage, and it is therefore not surprising that every day more and more new technologies are being introduced into various spheres of human life. The general computerization of our society has led to 4,100,667,287 Internet users on the planet in early 2019 , exceeding $53 \%$ of the total population of the Earth, and growing at a rapid rate. In the last 3 years the number of Internet users has grown by 3.42 billion (Internet Statistics..., 2019).

Why are innovative technologies so active in our lives? Because they greatly facilitate the existence of society itself, open up new opportunities for humanity, to do what was once considered impossible. But most importantly, they provide an opportunity to quickly find and 
acquire new knowledge that is so necessary in the process of our life. Thus, Google handles about 10 billion searches worldwide every day, and about $15 \%$ of them have never been used before (Internet Statistics..., 2019). Humanity is developing very rapidly, so education has a special place among all spheres of human activity (Riabovol et al., 2019). As technological advances grow, standards and requirements for education levels rise. These two phenomena have a dual relationship, as the world becomes more sophisticated with new technologies every day, which means that people also need to become smarter and adapt to these conditions.

The other side is the ambiguous impact of technology on the educational process, which has both positive and negative consequences. Education in its classical form is no longer able to meet the new requirements of scientific and technological progress and customers of educational services (Riabovol et al., 2019). That is why universities are increasingly beginning to apply new innovative techniques and research to improve the quality of education and its relevance to the rapid development of new technologies. One is the digitization of education, or the digital transformation of the entire educational activity of both the individual university and the education sector as a whole.

Digitization of education, which is primarily related to the introduction of the latest technologies in the educational process, has already been successfully implemented in many developed countries. To a great extent, its success depends on the level of state support, which in turn is determined by the public interests and needs of the population of different countries. Therefore, the level of development of the state, its internal and foreign policy, are of great importance for digitization. As for the needs of the population, the world practice and the trends in the development of education, they show that people really need it.

The issue of digitization of education in Ukraine is quite popular today and is widely discussed in society, in the media and even in political circles. Thus, according to the results of the First Conference of the National University of Kyiv-Mohyla Academy on teaching skills, which took place on 26.06.2018, on the basis of the Bologna process analysis, 5 trends of higher education in Europe were formulated, among which the main is the digitization of education, which is also defined as a means of realizing the other four (The first conference of teaching..., 2018). The new course of our country on informatization of the processes of public administration and creation in the new Government of Ukraine on 18.09.2019 of the Ministry of Digital Transformation (hereinafter - MDT) is the confirmation of the need to transfer of educational services in digital format, the main task of which was the realization of the National Program of Informatization (project "State in smartphone"). The purpose of this project is to provide most of its administrative services to its citizens as quickly as possible, electronically and online (2019). Such scale of initiatives by the state indicates that Ukraine is interested in the development of electronic digital technologies (digitization), and therefore the basis for such innovative transformations should be the new "digitized" education.

\section{Experience implementing digital learning in university practice}

The following methods were used during the research: general theoretical (analysis, synthesis, concretization, generalization, analogy method, modeling); empirical methods (research of experience of foreign countries on the implementation of educational digitization, development of a program of educational digitization in Ukraine, research of legal and scientific and methodological literature on the subject, scientific research and conclusions). The issue of digitization of education is extremely topical in developed countries. In education, Britain is a very successful country. This is facilitated by the active policy of the state, which fully supports innovative educational processes. One should also highlight the British legal environment, which is very conducive to digitizing education in all its aspects. By examining UK law, as well as the 
real world practice of using the latest digital technologies at Oxford and Open Universities, one can understand why Britain has made such advances in modernizing education.

It is worth starting with legal support, since education legislation in Britain is very extensive, linked to the features of the territorial system, and contains both general and specific rules that make it possible to fully implement the policy of digitization. In exploring the legal framework governing public relations in the United Kingdom's educational field, we believe it is advisable to highlight a few basic documents: "Education Act 2011", "Higher Education and Research Act 2017", "Technical and Further Education Act 2017", "Education and Adoption Act 2016", "Education and Skills Act 2008", "Further Education and Training Act 2007" (Education Act, 2011; Education and Adoption Act, 2016; Further Education and Training Act, 2007; Higher Education and Research Act, 2017; Technical and Further..., 2017; Education and Skills..., 2008; Education and Skills Act..., 2008). These legal acts regulate the issues of organization and functioning of education, establish general requirements and principles of this field, and other local acts are adopted in accordance with them. According to these documents, the digitization of education in Britain takes place in two directions - the technical improvement of educational and non-educational processes.

The main direction of digitization should be one that is aimed directly at the educational process. Its implementation is through the introduction of distance education. Section 2, Part 2, Section 1 of the "Higher Education and Research Act 2017", which is analogous to the Law of Ukraine "On Higher Education", provides a list of ways of teaching, among which the distance form is singled out as a special, separate form, which can be selected by everyone education. Thus, distance learning is a full-fledged educational process that includes educational and other activities, the quality of which is entrusted to the educational institution, and by the results of which a person can obtain a certain educational degree, confirmed by the relevant documents.

At first glance, this is a fairly general characteristic of the whole form of education, however, it is this act and its corresponding part that forms the basis for local acts. It in turn allows each educational institution to independently build its own policy and educational system, whereby universities are formed, which provide education only remotely or which have a mixed form. It is important to note that universities are not obliged to provide distance learning, it is their right, but it is actively used, because it is a real opportunity to provide education to a wider population, and it is also an opportunity for the use of new technologies, which also opens up new opportunities, for educational institutions as well as for people seeking or wanting education. Therefore, it can be noted that it is this norm that makes it possible to introduce digitization of educational processes (Higher Education and Research Act, 2017).

A great example of the digitization of education in action is The Open University, which was founded in 1969 under the Decree of the Queen of Great Britain. In its 50 years of existence, it has provided more than 2 million people with higher education. But, most importantly, most of the graduates of this university have been studying for the last 20 years, just as education legislation has undergone qualitative changes that have enabled innovative teaching methods. The introduction of new digital technologies in the educational process has opened up opportunities for The Open University to provide educational services worldwide. This institution has a distinctive functional structure, represented by Wollaton Hall and Milton Keynes administrative centers, thirty offices in different regions of the UK, a network of educational centers in more than fifty countries, a powerful official site and a dedicated computer program. Exploring the activities of this university, we have identified the following main functions:

- communication with the state, resolving organizational issues of activity, fulfillment of state tasks, implementation of state policy;

-communication with students and entrants, on the organization of the educational process; 
- examinations of students around the world, for the purpose of honest and objective assessment of knowledge that is conducted remotely, but directly in local institutions.

The official site is an important, special structural element, through which a large number of administrative functions are performed, including the provision of complete information about the university, feedback, students' personal cabinets and other, the concept of distance education, which is synonymously referred to as online education, is immediately explained (Statkevych, 2019). Digitization outside the educational processes in the UK is regulated in great detail by the state. The set of norms in different legal acts allows to implement a rather high-quality information policy with the involvement of technologies in universities. For example, paragraph 74 of the "Education and Skills Act 2008" allows the Internet to be used by the university to perform various functions, such as providing information, helping with various issues, financial support for research and etc. Just a few of the provisions of the "Technical and Further Education Act 2017" allow you to create and use relevant websites in education administration matters. "Education Act 2011" contains rules governing the use of electronic media and networks, namely, establishing liability for misuse of information stored therein. This rule also lays down rules for the use of different gadgets (smartphones, etc.) during the educational process, namely, prohibiting any activities that do not relate to the educational process and prohibiting them completely during the exam.

Actually, the University of Oxford (2020), which is considered one of the most prestigious in the world, uses its right to digitization outside of educational processes. A great example is its official website, which contains a large number of general administrative functions and several special ones aimed at helping students and enhancing the status of the university. Here we can find a section with all the information about the university, information sections for employees and students, news, scientific and creative blog, feedback data and more. There are several features that need to be distinguished, including a special news section for the media, i.e. Oxford University prepares special releases aimed at its own promotion. There is also a special section on political information outlining the university's stance on Brexit, stating that politics should not interfere with education, and therefore the close relationship of the institution with European countries will be inviolable, except for political reasons. Another interesting section is expert evaluation on various issues, i.e. the university provides official comments on events in various fields of human activity, with the involvement of specialists. There is also a section with online courses that give you the opportunity to earn an advanced degree, certified by an official certificate. The most important part is the "Jobs" section, which is a page of the site that informs about employment prospects after graduation. This page provides a list of university partners who may become your employers in the future. "The University's Strategic Plan" provides careeroriented assistance for hard-working and good students. In this way, the university is able to assist not only in education but also in the employment and further development of everyone.

The British model of digitization of education is a full-fledged one, envisaging the technical improvement of educational and non-educational processes, and it also opens up new opportunities for both students and universities. The clear legal regulation of some processes greatly facilitates their implementation, for example, the direct financing of such processes by the state within the framework of the implementation of its educational policy becomes available. It is important that British law not only provides online education, but also comprehensively controls it, making it today a quality and full-fledged education accessible to everyone.

However, in the matter of educational digitization, the United States of America is a leader today. In the US, technology is incredibly fast developing and being implemented in all walks of life, and especially in education. Such successes are ensured, first and foremost, by public policy, which not only allows but also comprehensively promotes technological progress. The active infusion of finance and the introduction of technology, combined with very high 
quality legislation, has led to the United States being one of the international leaders in the quality of education today. As of 2019, the American Education Index is 0.903 with a maximum value of 1 .

Precisely, quality legislation allows the United States to have such success. It has several features related to the territorial system and education system in the country, which aim at decentralizing education management. It should be noted that the general principles of the organization and functioning of the US education system are enshrined in two main legal acts "Elementary and Secondary Education Act of 1965" and "Higher Education Opportunity Act 2008 " in which the issue of digitization is very well developed and is one of the top priorities today. These acts not only introduced a mechanism for complete digitization of education, but also envisaged a procedure for its implementation, both by the state and universities.

Let's analyze each of them. For example, the "Elementary and Secondary Education Act of 1965 " is a legal act that regulates public relations in primary and secondary education in the United States. Significantly, in the context of our study, there is a rule that a significant portion of funding should go directly to the purchase and upgrade of technical equipment in schools and other institutions, with the aim of improving the educational process, this is primarily about arranging computer classes and using gadgets during class and more. And a special rule stipulates that the Internet should be accessible in every school, even in the most remote places (in towns, villages, etc.). Several legal rules introduce innovative digital technologies into the educational process at once. Thus, the legislation provides for the creation of entire individual training programs using technical means, or involving them in the classical program, and a considerable part of the educational materials is proposed to be translated into electronic digital form. The practical side concerns the actual application of all these innovations in the learning process, for which this law provides for two stages of implementation of these innovations:

- the first is the introduction of digital (technological) literacy lessons into the curriculum, that is, the teaching of students to use them in the learning process;

-the second is the practice of improving educational processes by technology, or the possibility of "digital education" (such a term is specified in the law, meaning it is a full-fledged training practice provided with technological means).

As a complementary practice, it is suggested to use a variety of online courses, with the consent of the teacher, and other digital opportunities. Thus, primary and secondary education in the United States is a period of initial introduction of technologies into the educational process, preparation for their use, and practice of their application. It is important that some processes and other aspects are regulated in great detail, there are clear lists of technical facilities and procedures. Each school, as well as higher education institutions in Europe, has an official website.

"Higher Education Opportunity Act - 2008" is a law on higher education which continues the practice of the previous one, and also develops issues of digitization, introducing novelties, while keeping the basics and trends introduced earlier. The main link of digitization here, as in the British counterpart, is distance education, as a separate, full-fledged form of education. In American law, the issue of remote work is very well developed, among other things, it is not just a general rule, but a detailed process, taking into account technical and other features. As in schools, technical equipment is constantly upgraded at higher education institutions. There are two types of distance education in the United States - full-time education and additional courses. Regarding its usual form, it is implemented in practice by the creation of entire online universities (similar to the British Open University), additional courses are implemented by introducing dual (or mixed) form of education in classical universities, through the introduction of online courses or through special separate projects. The law contains a list of technical support for distance education, among which are the main technical means and the Internet. 
A striking example of the introduction of digital technology in higher education is the Massachusetts Institute of Technology (MIT), which has a number of online projects in addition to standard administrative and other features, including a student startup section and online courses developed by the university (MIT - Massachusetts Institute..., 2020). An interesting practice is Harvard University (2020), where all administrative and other functions are located in students' personal online offices, and in addition to the startup project, there is another compatible with MIT, other universities and edX (non-profit educational platform) - an international platform with free online courses, in a variety of destinations and categories, is available worldwide.

In the USA the law not only provides for the digitization of education, but moreover, it actually promotes it. The prospect of this process is understood by the authorities of the United States of America, which is why, in addition to legal support, the state guarantees involvement in the education of material and technical investments, and not just public ones. The result of this symbiosis has been the availability of quality education in online universities, which is recognized by the world.

\section{Experience implementing digital learning in university practice}

Thus, foreign countries have many advances in technological modernization of education. The legal aspect of this issue plays a leading role, since digitization in the countries studied is systematic and at the national level, which accordingly provided such results. Adequate level of state support for the introduction of the latest technologies in the educational field, stipulated by special favorable legislation, under which special national programs for digitization are created. It is worth noting certain features, because in the American model, the digitization of education is an integral part of the legislation and the rules themselves contain both the program and the mechanism of its implementation, while in Britain the legislation provides for general permitting rules under which separate local programs are formed. Therefore, when it comes to the digitization of education at the state level, there are two necessary elements: favorable legislation and an appropriate program of action, which will include a real mechanism for the introduction of innovation, followed by a plan to implement these innovations.

The reform of national education, which has been introduced through the adoption of new regulations, which provide innovative legal foundations for the development of education of leading countries in the world, is gradually gaining momentum. Thus, the Law of Ukraine "On Higher Education" actually duplicates some of the rules of the British "Higher Education and Research Act 2017", including the provision on distance education, but in the domestic realities, it is very poorly implemented to an insufficient or incomplete extent. In other cases, the necessary provisions are simply absent, or do not operate under different circumstances, which, however, does not prevent volunteers, public figures and activists from developing ideas for technical improvement of education, promoting them in the media and promoting them. Accordingly, there is a rather strange situation in the country, when a certain process is already going on, and it is supported by the real interest and needs of the society, but does not have a clear plan of action and the necessary regulatory framework, according to which there are no real results.

The Ministry of Education and Science of Ukraine (hereinafter - MES) is pursuing a very active reform policy today. Significant efforts have been made to adapt the Ukrainian system to European standards, whereby digitization is one of the leading areas of MES activity. In spite of this, there is no clear program of educational digitization of education in Ukraine today, and all the ongoing processes can be summarized and called a preparatory stage. The process of decentralization in all public spheres is also important here, so that the initiative and material capacity of local communities across the country play an important role in technical improvement, which is also complicated by the peculiarities of the geopolitical system and the lack of direct channels of financing. Therefore, the creation of a separate, full-fledged branch of digital 
education is still not discussed, although it is clear that it is only a matter of time. At present, only the initial conditions of digitization are forming (Berbeniuk, 2019).

In the initial stage of digitization, MES faced the problem of territorial contrast in education and providing training. The fact is that in villages and other small settlements, the level of financial support is lower than in the same cities, according to which a large number of educational establishments still do not have Internet connection (as of early 2019, about one third of schools have no access to network), which is the basic element of digitization. A related technical issue related to the lack of up-to-date equipment in schools (computers, multimedia devices, etc.). The solution to these problems is foreseen in the plan of MES and the state budget of 2019, which is planned to spend more than 1 billion hryvnias (Borovets, 2019).

MES has already acquired the National Educational Electronic Platform (hereinafter NEEP). The main focus of the project is the reform of general secondary education in Ukraine within the framework of the "New Ukrainian School" reform. The aim of the project is to provide free access to e-learning materials for all participants in the educational process, which will make the education more qualitative and accessible. The platform is currently in test mode and is being prepared for implementation. The exact concept of the NEEP is currently unknown, but in the future it will not only be a source of educational materials, but also a space for the implementation of interactive learning tools (interactive laboratories, virtual museums, etc.), communication with teachers and even education management systems. The Institute for the Modernization of Content of Education, which deals with the implementation of NEEP, plans that this platform "should be the engine of significant changes in the educational process and start the market for the production of electronic educational products and services, will help to shape the digital competence of participants in the educational process in Ukraine". "The National Educational Electronic Platform Regulations" have been developed for the start-up of NEES across Ukraine, by the MES experts, the Institute for the Modernization of the Content of Education and the Office of Effective Regulation (Content of Education..., 2018). In general, it can be assumed that the launch of the NEEP will be the beginning of the first stage of digitization.

The experience of cooperation between MES and Google is quite unique for Ukraine. Thus, on November 22, 2018, negotiations were held in Kyiv between the former Minister of Education and Science of Ukraine Liliya Hrynevych and a representative of the world corporation. During the conversation, a representative Doron Avni said that the company is pleased to cooperate more closely with Ukraine, and offered to hold a conference on secure Internet, which the Minister immediately agreed (More Opportunities..., 2019). The next question concerned cooperation on school equipment requirements, initially through consultative relationships, with a possible transition to partnerships. "Now we are ready to invest resources for the introduction of modern technologies in the educational process. But we need comprehensive and high-quality expertise to recommend the most modern and effective solutions. We want budget funds to be used to the maximum benefit of children, but we cannot carry out such expertise on our own", - Liliya Hrynevych explained.

From this quote, the ex-minister can understand that the MES understands the need and prospects of digitization, but the following problem is immediately highlighted - this is an insufficient level of competence in such matters, which is caused by the lack of previous experience, as well as by the fact that it is difficult to argue that the overall level of domestic technological development is somewhat behind the foreign one. The other two issues are closely related, namely, legal and financial matters. Secondly, it all boils down to the need for significant financial investments in the process of digitization, not only for the purchase of technical equipment, but also for the production of digital teaching materials, the retraining of teachers and educators, and other processes aimed at creating a state-owned institute of full-fledged online education. 
In any case, the value of the project is undeniable, because even in one of the previous examples, it was necessary to allocate more than one billion hryvnias to solve the basic technical issue, given that the decision-making process is still ongoing and it is unknown whether it will be completed in time, and whether additional funds will be needed given the volatility of the financial system and pricing policy in the information technology market. The financial problem is directly related to legal support, because current law allows it, but it does not guarantee a direct flow of money into all these processes, so they are not just slowed down and sometimes do not even begin. The processes of digitization are unregulated, and therefore there are no mechanisms for its implementation and realization. Generalizing is the problem of the lack of a state program (plan) for the digitization of education, if there is a real need. The MES position is favorable in this regard. In fact, activities in this direction have already begun. Solving all current problems will finally create the necessary environment and start the process of digitization. In solving problems, it is necessary to focus on the successful experience of the leading countries of the world and in the future to cooperate with them in this field. In our opinion, it is possible to implement a complete concept of digitization at the state level. Therefore, it is possible to determine the general criteria that must be met by the process of digitization of education in Ukraine: processes);

- the generality (taking into account all levels of education and outside the educational

- globality (the correctness of territorial policy in terms of digitization, equalization of the rights and opportunities of all the objects targeted by the process of improvement, orientation towards the further exit of education beyond the state border and the prospect of international cooperation);

-innovation (compliance with world standards, in matters of legal and technical support, constant focus on comprehensive education upgrades);

-two-sidedness (active interaction of all parties in the process of digitization, promptness in solving problems, compliance with basic needs).

An example and basis for the digitization of education could be the nationwide project "State in Smartphone", which is currently in its infancy. The basic concept of "E-government" (state digitization) is the transfer of public services to the online mode, which was approved by the Cabinet of Ministers in 2010, but active work has only lasted for the last 3 years. In the meantime, the Ministry of Economic Development, together with the State Agency for Electronic Governance, has transferred over 120 services to citizens and businesses online. Already today, you can register a child, business, take extracts from the registry, get help, licenses and certificates. A special innovation was the taxpayer Cabinet, which also led to the introduction of a digital signature (Prokaza, 2019).

Already at this stage there is a problem of branching, according to which there are about 350 state registers in Ukraine which are not related (Manzhula et al., 2019). Another problem is the quality of the registers, because according to the experts of the TAPAS (USAID/UK aid "Transparency and Accountability in Government and Services/TAPAS") project, some state databases duplicate up to $80 \%$ of information, besides the information contains errors, and registration is made by different standards. Within the framework of digitization, it is necessary to develop uniform state standards for digital materials and their work. In the future, it is planned that public authorities will register all their information resources on a single web portal, which will also house relevant online services - this is about the general concept of state digitization. The project aims not only to facilitate the provision of public services, but also to improve their quality. Among other things, it is one of the ways to implement a state anti-corruption policy, as digital service significantly reduces the "human factor" in service delivery, which in turn is the main cause and link of corruption schemes. 
The real achievement in the sphere of state digitization can be considered the creation of a new ICT transformation of Ukraine. The main activity of the Ministry is related to the formulation and maintenance of the state policy in the sphere of state digitization and development of citizens' digital skills. By 2024, the ministry plans at the legislative level: transfer and consolidate $100 \%$ of public services for the public and businesses online, provide high-speed Internet with $95 \%$ of transport infrastructure, settlements and their social facilities, involve 6 million Ukrainians in the digital skills development program. It is also planned that the share of information technologies in the GDP of Ukraine will be at least 10\%. The Ministry has an important duty to develop digital legislation (the main focus is e-governance). In fact, state digitization was one of the main reasons for the creation of a new Ministry.

Given the above, we can say that in matters of privatization, the state is ready for decisive action. There is a clear link between the effectiveness and the availability of a government program in digital modernization. In the context of education, "The State in the Smartphone" promotes the formation of appropriate conditions for the transition of national education to a new digital level. Today, education in Ukraine is governed by a large number of legal acts, among which the main ones are the Laws of Ukraine "On Education", "On Preschool Education", "On General Secondary Education" and "On Higher Education". These laws regulate national education at all levels. The general educational policy of Ukraine is contained in the Law of Ukraine "On Education". In the context of digitization, this act actually has a good regulatory framework for innovation. Part 1 of Article 9 of Section I contains a list of forms of education where distance education is defined as the main one. Here, in Part 4, the distance form is interpreted as based on the use of information and communication technologies (direct authorization to provide and implement training through technology).

The special provision in Article XIII (3) of Section XII allows general secondary education institutions to create in their composition classes (groups) with evening (extramural), distance learning (a similar provision is also provided in the law "On Higher Education"). Part I of Article 3 of Section I provides for free access to educational materials, including, among other things, separate e-learning materials and access to the Internet, also Article 75, Section 5 of Section IX provides that the central executive authority in the field of education and science provides for the establishment and operation of a special information resource on the Internet, which hosts free e-learning materials. Article 72, Section 3, Section VIII also provides for the availability of statistics on education in Ukraine freely available on the Internet. Section 1, Paragraph 1, Section I provides an interpretation of digital educational material as a systematic educational material that is educational and contains objects of different formats (i.e. not only text form, but also other forms such as video, etc.). Several other provisions suggest, and in some cases impose, the obligation of schools to use websites to promote reporting and openness, as well as to ensure information-sharing processes etc. There are also other norms that are aimed at improving the educational process.

The Law of Ukraine "On Preschool Education" has been little adapted to the conditions of digitization, precisely because of the lack of direct norms, which in turn can be explained by the subject of regulation of this law (Law of Ukraine "On Preschool..., 2001). However, for example, the experience of the United States ("Elementary and Secondary Education Act of 1965 ") suggests that digital literacy lessons can and should be introduced into the curriculum in the early stages of learning. Such changes are actually needed in the context of digitization. They are easy to implement in accordance with the Law of Ukraine "On Education" (as this law applies to all levels of education and its provisions allow for such qualitative changes). The Law of Ukraine "On General Secondary Education" Part 3 of Article 8 of Section II duplicates the provision of the Law "On Education" on the creation of special classes (groups) for distance learning. There are little special rules regarding the digitization in this law, which in turn is justified by the presence of all relevant rules in the same law "On Education", the effect of which it applies and according to which it was adopted (Law of Ukraine "On General..., 1999). 
The Law of Ukraine "On Higher Education", in accordance with the general educational legislation, provides for extramural learning (distance education) in paragraph 2 of Part 1 of Article 49, also part two of the same Article stipulates that the forms may be combined (Law of Ukraine "On Higher..., 2014). In order to ensure the organization and activities of student selfgovernment, the scientific society (in accordance with Articles 40, 42 of Chapter VII), educational institutions must, in order to ensure proper conditions, provide access to the Internet. Part 44, Article 44, Section VII also guarantees the providing people with special status with the Internet in the care of them. The law also establishes monitoring of graduates' employment rates and the dissemination of data via the Internet (Article 64, Part 5, Section X). At the same time, several rules propose and impose a duty to use websites for the organization of educational, noneducational as well as administrative aspects of education. Other aspects of digitization are also governed by the general law "On Education" and the relevant legal acts in the field.

Among other things, the by-laws are worth highlighting, which in this area are large in number, starting with the educational program and to the local acts of educational institutions, which in turn also contain provisions relating to the digitization of the educational process. For example, the Decree of the Cabinet of Ministers of Ukraine No. 87 "On Approval of the State Standard for Primary Education" of February 21, 2018 provides for a large number of relevant norms, including promotion of information and communication competence, including digital literacy (paragraph 7 of Part 7), or requirements for protecting information and its legitimacy when using websites by educational institutions, etc. (Decree of the Cabinet of Ministers..., 2018). Among other things, the field of education, especially in matters of digitization, is regulated by a large number of information and even social legislation, not to mention economic and other fields.

\section{Conclusions}

A general analysis of the Ukrainian legislation in the field of education shows that it is actually adapted to the process of digitization. It should be noted that in some issues it is better than the British, but it is inferior to the details in comparison with the American one, which in turn does not interfere with the beginnings of technical improvement of education. Small additions and adjustments to different microprocesses can be made directly during digitization, which will also allow them to be adapted immediately to their current needs, thereby making them more profitable and effective under reform. Therefore, it can finally be argued that the domestic legislation allows and promotes the introduction of a new educational reform on the digitization of education in Ukraine, according to which the success and reality of this process depends on the development and implementation of a program (plan) of actions.

Taking into account our research, we propose a program of digitalization of education in Ukraine, which will contain the plan and mechanism of introduction and realization of innovations. This program includes several steps at once, due to the scale of the reforms. Stage I - preparatory. At this stage, the MES and the ITC are beginning to actively cooperate on the current educational environment before further technical modernization. The main tasks of the MES at this stage are the following:

1) Establishment of a dedicated Department of Education Digitization, which will carry out specific audits at various stages of the reform, provide reporting on this issue, organize cooperation with the ITC and work on the development of legislative changes;

2) Conducting a nationwide check of the level of technical support of all educational institutions, availability of Internet access, modern equipment (multimedia technologies, quality computer classes, etc.). According to the results of the audit, to form a rating according to which the most affluent educational institutions should be allocated as a possible basis for the creation 
of online units based on them. Highlight institutions that need immediate upgrading and increased targeted funding from the same ranking;

3) Putting into operation the NEEP, its modernization as a center for all-Ukrainian online education, and a basic information and administrative resource.

4) Begin preparation of legislative reform on the issues of educational digitization:

- development of new mandatory provisions in the law "On education" on mandatory digital literacy lessons at preschool level (which are currently absent in the law "On early childhood education");

- creation of appropriate discipline at the secondary education level (introduction of special standards and requirements for the level of digital skills of participants of the educational process (not only students and teachers).

Prepare the necessary acts that will regulate the creation of online learning institutions based on existing ones (legislative interpretation, their organization and functioning), as well as acts on the training of digital educational establishments (training and certification of teachers and researchers) and the preparation of training programs at all levels of education.

\section{References}

Berbeniuk, I. (2019). Digitization of education is the competence of XXI century. Education. Retrieved from: https://cutt.ly/6rquNkH

Borovets, L. (2019). Why the MES priorities for 2019 do not respond to the challenges of school education. The Ukrainian Truth of Life. Retrieved from: https://cutt.ly/irhQXw3

Content of education and the office of effective regulation. (2018). Retrieved from: https://zakon.rada.gov.ua/laws/show/z0702-18.

Decree of the Cabinet of Ministers of Ukraine "On Approval of the State Standard for Primary Education". (2018). Retrieved from: https://zakon.rada.gov.ua/laws/show/87-2018$\% \mathrm{D} 0 \% \mathrm{BF}$

Education Act. (2011). Retrieved from: https://cutt.ly/MrhQ3C8

Education and Adoption Act. (2016). Retrieved from: https://cutt.ly/PrhQ7tF

Education and Skills Act 2008. (2008). Retrieved from: http://www.legislation.gov.uk/ukpga/2008/25/contents

Further Education and Training Act. (2007). Retrieved from: https://cutt.ly/HrhQmar

Harvard University. (2020). Retrieved from: https://cutt.ly/DrhQEPz

Higher Education and Research Act. (2017). Retrieved from: https://cutt.ly/rrhQTjT

Internet statistics 2019: traffic, sites and blogs, domains, social media, online advertising and ecommerce - latest figures and facts. (2019). Retrieved from: https://cutt.ly/Erhmrlf

Law of Ukraine "On General Secondary Education". (1999). Retrieved from: https://cutt.ly/Krqu8yk

Law of Ukraine "On Higher Education". (2014). Retrieved from: https://cutt.ly/Krhmb5i

Law of Ukraine "On Preschool Education". (2001). Retrieved from: https://cutt.ly/Lrqu86j

Manzhula, A., Harust, Y., Myrhorod-Karpova, V., Sobol, Y. (2019). Search for ways to optimize the activities of state bodies managing the funds of international technical assistance. Asia life Sciences, 2, 119-129.

MIT - Massachusetts Institute of Technology. (2020). Retrieved from: https://web.mit.edu/

More Opportunities from Schools and Institutions of Professional Education to Higher Education and Scientific Institutions - MES Identifies 10 Priorities for 2019. (2019). Retrieved from: https://cutt.ly/HrquVFN

Prokaza, D. (2019). E-country: when the Ukrainian state will be in the smartphone. Retrieved from: https://cutt.ly/urquBRT

Riabovol, L., Harust, Y., Dzhafarova, O., Sobol, Y. (2019). Students' scientific activity as a component of the lawyers' professional training. Asia life Sciences, 2, 144-156.

Statkevych, A.H. (2019). Establishment of a UK Open University (historical aspect). Retrieved from: http://eprints.zu.edu.ua/2460/1/138-141.pdf 
Technical and Further Education Act 2017. (2017). Retrieved from: https://www.evershedssutherland.com/global/en/what/articles/index.page?ArticleID=en/Education/EDU_TEC HNICAL AND FURTHER ACT

The first conference of teaching skills took place in Mogilyanka. (2018). National University of Kyiv-Mohyla Academy.

Retrieved

from:

https://www.ukma.edu.ua/index.php/news/3840-u-mohyliantsi-vidbulasia-pershakonferentsiia-vykladatskoi-maisternosti

University of Oxford. (2020). Retrieved from: http://www.ox.ac.uk/. 